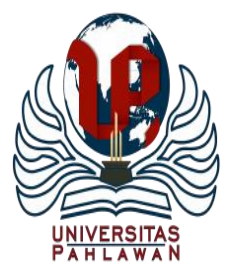

Edukatif : Jurnal Ilmu Pendidikan Volume 3 Nomor 5 Tahun 2021 Halm 2032 - 2039

EDUKATIF: JURNAL ILMU PENDIDIKAN

Research \& Learning in Education

https://edukatif.org/index.php/edukatif/index

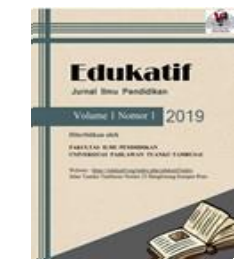

\title{
Pengembangan Media Pembelajaran Berbasis Video Naratif dengan Metakognitif pada Materi Ketenagakerjaan
}

\author{
Fitria Cholifatoul Muthoharoh \\ Universitas Negeri Surabaya, Indonesia \\ E-mail : fitria.17080554062@mhs.unesa.ac.id
}

\begin{abstract}
Abstrak
Media pembelajaran merupakan salah satu aspek pendukung dalam kegaiatan pembelajaran terutama dalam masa pandemi seperti saat ini, kebutuhan akan media pembelajaran yang tepat dan memudahkan siswa maupun guru dalam pelaksanaan proses pembelajaran sangat dibutuhkan. Penelitian pengembangan ini bertujuan untuk mendeskripsikan tingkat kelayakan; menganalisis keefektifan melalui ketuntasan hasil belajar; serta kepraktisan dalam penggunaan media melalui angket respon yang diberikan kepada siswa dan guru. Jenis penelitian yang digunakan yaitu R\&D (Research and Development) dengan model penelitian ADDIE oleh Dick \& Carry dan menggunakan model ujicoba one-group pretest-posttest design. Hasil penelitian menunjukan persentase validasi kelayakan media sebesar $80 \%$ termasuk dalam kategori “Layak". Sedangkan dalam aspek keefektifan diperoleh skor sebesar 85\% dengan kategori "Baik". Serta skor kepraktisan diperoleh presentase sebesar $89.18 \%$ dengan kategori "Sangat baik". Sehingga dapat disimpulkan bahwa media pembelajaran berbasis vide naratif dinyatakan layak untuk digunakan dalam prose pembelajaran dan menjadi solusi media pembelajaran yang efektif, dan praktis digunakan dalam pembelajaran pada masa pandemi.
\end{abstract}

Kata Kunci: Pengembangan media pembelajaran, video naratif, metakognitif, hasil belajar.

\begin{abstract}
Learning media is one of the supporting aspects in learning activities, especially during a pandemic like today, the need for appropriate learning media and making it easier for students and teachers in implementing the learning process is very much needed. This development research aims to describe the level of feasibility; analyze the effectiveness through the completeness of learning outcomes; and practicality in the use of media through response questionnaires given to students and teachers. The type of research used is $R \& D$ (Research and Development) with the ADDIE research model by Dick \& Carry and using a on e-group pretest-posttest design trial model. The results showed that the percentage of media feasibility validation was $80 \%$ included in the "Eligible" category. Meanwhile, in the aspect of effectiveness, a score of $85 \%$ was obtained in the "Good" category. As well as the practicality score obtained a percentage of $89.18 \%$ in the "Very good" category. So it can be concluded that the narrative video-based learning media is declared feasible to be used in the learning process and becomes an effective learning media solution, and is practically used in learning during the pandemic.
\end{abstract}

Keywords: Development of instructional media, narrative video, metacognitive, learning outcome.

Copyright (c) 2021 Fitria Cholifatoul Muthoharoh

$\triangle$ Corresponding author

Email : fitria.17080554062@mhs.unesa.ac.id

DOI : https://doi.org/10.31004/edukatif.v3i5.713

ISSN 2656-8063 (Media Cetak)

ISSN 2656-8071 (Media Online)

Edukatif : Jurnal Ilmu Pendidikan Vol 3 No 5 Tahun 2021 p-ISSN 2656-8063 e-ISSN 2656-8071 


\section{Pengembangan Media Pembelajaran Berbasis Video Naratif Dengan Metakognitif Pada Materi Ketenagakerjaan - Fitria Cholifatul Muthoharih \\ DOI : https://doi.org/10.31004/edukatif.v3i5.713}

\section{PENDAHULUAN}

Pembelajaran pada masa pandemi seperti saat ini memerlukan banyak penyesuaian baik dari segi proses pembelajaran maupun media yang digunakan. Dalam hal media pembelajaran, diperlukan berbagai pembaharuan dan inovasi yang menyesuaiakan kebutuhan pembelajaran jarak jauh. Pembaharuan dan inovasi dalam pendidikan melibatkan berbagai pihak salah satunya yaitu pendidik yang dalam hal ini dikatakan sebagai fasilitator yang diharuskan untuk terampil dalam hal tersebut baik melalaui penggunaan media pembelajaran atau lainya agar pebelajaran yang dilakukan mampu berpusat pada peserta didik (Astra, I Made \& Wahidah, 2017, p. 2). Kondisi pembelajaran jarak jauh berdampak pada ditemuinya beberapa kondisi yang berbeda dari lainya, hal ini sejalan dengan pendapat (Mansyur, 2020) yang mengatakan bahwa dalam kondisi pandemi terdapat beberapa hal yang berdampak dalam proses pembelajaran diantaranya: 1) pembelajaran di sekolah dialihkan ke rumah dengan proses pembelajaran secara online atau daring; 2) adanya transformasi penggunaan media pembelajaran berbasis teknologi diantaranya penggunaan Google Classroom ,Wathshap Group, Zoom, Microsoft Teams dan Youtube; 3) perubahan metode yang digunakan dalam pembelajaran; 4) penyesuaian metode evaluasi pembelajaran sebagai penentu standar kenaikan kelas dan kelulusan; dan 5) perlunya peran orangtua di rumah sebagai fungsi pengawas yang sebelumnya dibebankan kepada guru disekolah.

Penelitian pengembangan ini dimaksudkan untuk meningkatkan keaktifan serta partisipasi peserta didik dalam proses pembelajaran yang berdampak padapeningkatan hasil belajar peserta didik yang didukung oleh penelitian terdahulu yang telah dilakukan. Diantaranya memaparkan bahwa penggunaan media pembelajaran berbasis video mampu menjadi alternatif media pembelajaran untuk pemebelajaran daring dan meningkatkan hasil belajar siswa (Muhammad iqbal, sri latifah, n.d.). dengan penegertian media sebagai suatu perangkata yang dapat menyalurkan informasi ke penerima (Martinis Yamin, 2012) selain itu penggunaan media pembelajaran video berbasis materi dan soal juga ammapu meningkatkan penguasaan konsep IPA oleh siswa (Nanang Soffiyullah, 2015) selanjutnya ada penelitian yang dilakukan oleh (Hafiz, 2013) mengenai peningkatan hasil belajar siswa dengan penerapan media pemebelajaran dala prosesnya. Dari penelitian terdahulu yang telah dipaparkan sebelumnya belum ada yang menggunakan media pembelajaran video yang berbasis audio naratif serta pada mata pelajaran ekonomi materi ketenagakerjaan serta penerapanya dalam pembelajaran jarak jauh. Sehingga dipilihlah metode pengembangan Research and Development (R\&D) yang menghasilkan produk berupa media pembelajaran sesuai dengan kebutuhan guru dan peserta didik selama proses pembelajaran jarak jauh.

Hal ini didasari oleh hasil observasi dan wawancara yang dilakukan di SMA Negeri 1 Soko, bahwa ditemukan adanya kendala dalam proses pembelajaran secara daring atau jarak jauh, dimana pembelajaran hanya terbatas pada metode ceramah melalui whastapps group ataupun video conference, siswa juga tidak cukup memiliki bahan pembelajaran untuk dipelajari secara mandiri sedangkan proses pembelajaran secara daring menuntut siswa mampu memahami sebagian besar materi secara mandiri sebab waktu pembelajaran daring yang terbatas. Seringkali guru harus mengulang kembali pembahasan terdahulu sebab keterbatasan waktu pembelajaran yang mana hal ini berdampak pada pengurangan waktu pembelajaran untuk memebahas materi selanjutnya. Maka dari itu media pembelajaran berbasis video naratif perlu diterapkan dalam pembelajaran jarak jauh sebab mampu menjadi solusi bagi siswa untuk dapat belajar secara mandiri dengan lebih mudah dengan menggunakan media yang tidak hanya dilengkapi dengan narasi materi tetapi juga gambar ilustrasi pendukung yang menarik sehingga terciptalah pembelajaran jarak jauh yang praktis, efektif dan efisien karena media pembelajaran berbasis video naratif dapat diakses dimana saja kapan saja.

Berdasarkan latar belakag yang telah dipaparkan di atas, serta perbedaan penelitian yang dilakukan peneliti dengan oenelitian sebelumnya yaitu kebutuhan media untuk proses pembelajaran secara daring maka dikembangkan penelitian dengan judul " Pengembangan Media Pembelajaran Berbasis Video Naratif Dengan Pendekatan Metakognitif Pada Materi Ketenagakerjaan Kelas XI SMA Negeri 1 Soko”yang berbeda dengan 
penelitian sebelumnya karena penerapanaya dimasa pandemi dan juga jenis video yang berupa video naratif yang memuat materi yang disertai ilustrasi pendukung sebagai solusi peningkatan keaktifan dan antusiasme serta hasil belajar peserta didik.

\section{METODE PENELITIAN}

Dalam penelitian pengembangan ini peneliti menggunakan jenis penelitian dan pengembangan (Research and Development), menurut (Sukamadinata, \& Nana, 2009) penelitian pengembangan merupakan suatu proses atau langkah-langkah untuk mengembangkan suatu produk baru atau menyempurnakan produk yang telah ada dan dapat dipertanggungjawabkan. Sedangkan untuk metode yang digunakan dalam penelitian yaitu metode penelitian dan pengembangan $(\mathrm{RnD})$ yang diharapkan mampu menghasilkan produk media pembelajaran yang efektif digunkan dalam proses pembelajaran. Sedangkan untuk prosedur penelitian digunakan model ADDIE yang dinilai sebagai model pengembangan yang praktis digunakan dan mampu diterapkan dalam kurikulum yang berlaku yang terdiri dari 5 tahap, diantaranya : analysis, design, development, implementation dan evaluation. (L, 2016, p. 4). Subjek dalam penelitian pengembangan ini merupakan 20 siswa kelas XI di SMA Negeri 1 Soko yang menggunakan teknik pengumpulan data berupa wawancara bersama guru mata pelajaran ekonomi, observasi pembelajaran dikelas dan pembelajaran daring untuk melihat kendala yang dialami peserta didik maupun guru dalam proses pembelajaran. Analisis menggunakan skala likert untuk lembar telaah dan validasi serta skala guttman untuk angket respon guru dan peserta didik. Teknik analisis data dalam penelitian ini menggunakan teknik analisis deskriptif kualitatif kuantitatif. Analisis data hasil validasi dan angket dilakukan dengan rumus berikut ini:

\section{Persentase $(100 \%)=\underline{\text { Jumlah Skor } \times 100}$ \\ Skor Maksimal}

Tabel 1. Hasil analisis dipaparkan dengan kriteria penilaian sebagai berikut :

\begin{tabular}{lll}
\hline No & Persentase & Keterangan \\
\hline 1 & $00 \%-20 \%$ & Sangat Tidak Valid \\
\hline 2 & $21 \%-40 \%$ & Tidak Valid \\
\hline 3 & $41 \%-60 \%$ & Kurang Valid \\
\hline 4 & $61 \%-80 \%$ & Valid \\
\hline 5 & $81 \%-100 \%$ & Sangat Valid \\
\hline
\end{tabular}

\section{HASIL DAN PEMBAHASAN PENELITIAN}

Hasil dari penelitian pengembangan video naratif pada materi ketenagakerjaan kelas XI SMA Negeri 1 Soko dipaparkan dengan hasil disetiap tahapanya: Tahap analisis (analysis). Pada tahap ini tujuan yang ingin dicapai yaitu dapat menetapkan dan mendefinisikan syarat-syarat pembelajaran. Pada tahap ini juga dilakukan analisis mengenai intrumen penilaian pembelajaran ekonomi dan kebutuhan pembelajaran ekonomi lainya. Analisis dilakukan secara langsung melalui wawancara dengan guru dan peserta didik. Hasil dari pengkajian analisis ini akan dijadikan landasan dalam mengembangkan produk, diantaranya adalah analisis kebutuhan, kurikulum dan karakteristis peserta didik. Serta tujuan yang ingin dicapai setelah proses pembelajaran seperti pada gambar dibawah ini: 


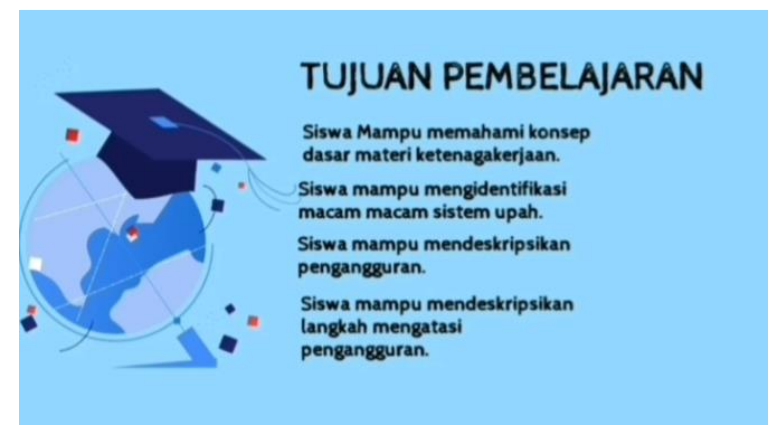

\section{Gambar 1 Tujuan Pembelajaran}

Dengan adanya tujuan pembelajaran yang ingin dicapai diharapkan peserta didik mengetahui target pencapaian apa saja yang dapat terpenuhi dengan penggunaan media pembelajarn video naratif terutama untuk materi ketenagakerjaan. Selanjutnya diberikan apersepsi atau pengulasan materi sebelumnya untuk merefresh kembali memori peserta didik mengenai materi yang telah dipelajari sebelumnya:

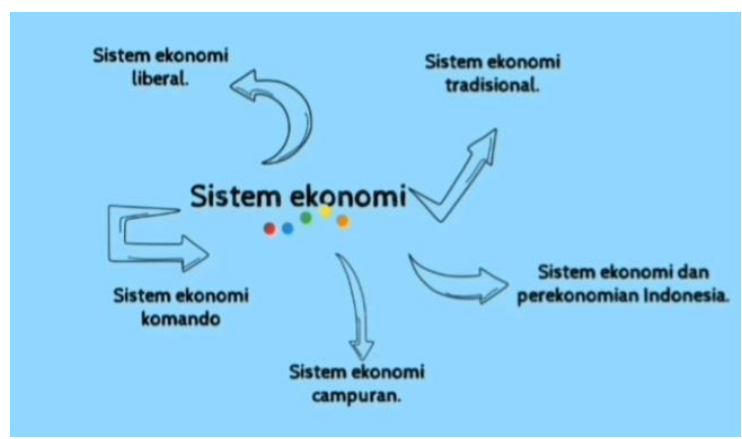

\section{Gambar 2 Apersepsi ulasan materi sebelumnya}

Tahap perancangan (design). Tujuan dari tahap perancangan ini adalah menemukan langkah yang lebih efektif dan efisisen untuk mengembangkan rancangan produk awal berdasarkan diawalai dengan pemilihan media kemudian formatnya berdasarkan data-data yang diperoleh dari tahap pendefinisian.

Tahap pengembangan (development). Pengembangan media pembelajaran video naratif melalui 2 tahapan yaitu : a) Telaah dan validasi ahli yang selanjutnya mendapatkan saran dan masukan dari dosen ahliyaitu Bapak Albrian Fiky Prakoso S. Pd., M.Pd. dengan rincian sebagai berikut

Tabel 2 Hasil Telaah Ahli

\begin{tabular}{lrl}
\hline Nama & Komentar dan Saran Perbaikan \\
\hline Albrian Fiky Prakoso S. Pd., M.Pd & Materi pembelajaran yang dituju sangat \\
& tepat sebab tergolong pada materi yang \\
& padat dan perlu pembahasan lanjutan. \\
& Media pembelajaran vide naratif sangat \\
& praktis dan efisien sebab bias diakses \\
& dimana saja dan kapan saja serta memuat \\
& materi secara sederhana tapi mendalam \\
$\bullet$ & Audio naratif yang disertakan mendukung \\
& teks dan ilutrasi yang ditampilkan \\
\hline
\end{tabular}

Sumber: Data diolah peneliti

Berdasarkan pemaparan hasil telaah ahli diatas dapat disimpulkan bahwa media pembelajaran video naratif layak untuk digunakan dalam proses pembelajaran jarak jauh dan mampu memenuhi kebutuhan serta menjawab keluhan baik guru maupun peserta didik dalam menghadapi kendala pembelajaran jarak jauh.

\section{Tabel 3 Hasil Validasi Ahli}


2036 Pengembangan Media Pembelajaran Berbasis Video Naratif Dengan Metakognitif Pada Materi Ketenagakerjaan - Fitria Cholifatul Muthoharih

DOI : https://doi.org/10.31004/edukatif.v3i5.713

\begin{tabular}{lll}
\hline Aspek Validasi & Hasil Keseluruhan & Kriteria \\
\hline Materi & $80 \%$ & Valid \\
\hline Media & $80 \%$ & Valid \\
\hline Keefektifan & $85 \%$ & Sangat valid \\
\hline Kepraktisan & $89,18 \%$ & Sangat valid \\
\hline \multicolumn{2}{r}{ Sumber: Data diolah peneliti } \\
\end{tabular}

Berdasarkan data validasi dari para ahli, validasi dari aspek mandiri mendpat skor presentase sebesar $80 \%$ dengan kategori valid atau layak, validasi dari aspek media mendapat skor presentase sebesar $80 \%$ dengan kategori valid atau layak, validasi tingkat keefektifan dengan skor $85 \%$ dengan kategori sanagat valid atau sangat layak serta validasi tingkat kepraktisan mendapat skor presentase sebesar 89,18\% dengan kategori sangat valid atau sangat layak.

Tahap implementasi (implementation). Pada tahap ini dilakukan penerapan proses pembelajaran dengan menggunakan media pembelajaran yang dikembangkan yaitu media embelajaran video naratif dengan pendekatan metakognitif pada amteri ketenagakerjaan untuk kelas XI SMA Negeri 1 Soko. Tahap ini sekaligus menjadi tahap uji coba produk.

Tahap evaluasi (evaluation). Tahap evaluasi dilakukan setelah penerapan media pembelajaran video naratif di kelas XI SMA Negeri 1 Soko. Hasil evaluasi dianataranya: 1) perlunya penambahan soal kuis dalam video, 2) pengembangan lanjutan media untuk materi selain ketenagakerjaan.

Pembahasan lanjutan dari penelitian pengembangan video naratif dengan pendekatan metakognisi materi ketenagakerjaan kelas XI SMA Negeri 1 Soko sebagai berikut:

Kelayakan video naratif dengan pendekatan metakognitif pada materi ketenagakerjaan kelas XI SMA Negeeri 1 Soko dapat dilihat dari hasil telaah dan validasi dari para ahli diberbagai aspek baik materi maupun media dengan presentase sebesar $80 \%$ untuk keseluruhan hasil telaah ahli dan $80 \%$ untuk hasil keseluruhan validasi para ahli.

Hal ini sejalan dengan penelitian sebelumnya (Rony Yudhi Septa Priana, 2017) yang mengungkapkan bahwa media pembelajaran video layak digunakan dalam proses pembelajaran peserta didik. Sama halnya dengan peneltian lainya (M. Bahri Arifin, 2020) juga penelitian oleh (Anjar Purba Asmara, 2015) yang mengungkapkan bahwa media berbasis audio visual menjadi salah satu media pembelajaran yang layak untuk diterapkan dalam proses pembelajaran.

Keefektifan video naratif dengan pendekatan metakognitif pada materi ketenagakerjaan kelas XI SMA Negeeri 1 Soko ditandai dengan peningkatan hasil belajar siswa yang diawali dengan pengadaan pretest dan posttest sebelum dan sesudah penggunaan media. Persentase ketuntasan pada saat Posttest sebesar $85 \%$ dengan kategori "sangat baik". Dengan presentasi ketuntasan prestest sebesar 0\% Terdapat peningkatan jumlah siswa yang memeperoleh skor ketuntasan diatas KKM.

Hal ini sejalan dengan salah satu syarat suatu media dikatakan efektif selain juga antusiasme siswa dalam penggunaan media (Hafiz, 2013) Terdapat 17 siswa tuntas dan hanya 3 siswa yang tidak tuntas. Adanya siswa yang tidak tuntas dalam tes kemampuan siswa disebabkan kurangnya antusias siswa tersebut dalam pembelajaran. Selain itu beberapa siswa juga cenderung tidak menyimak materi dalam media pembelajaran video naratif dengan keseluruhan.

Skor keefektifan media pembelajaran naratif ini sejalan dengan penelitian yang dilakukan oleh (Marhani, Aunurrahman, 2012) penelitian tersebut berjudul pengembangan media video untuk perolehan belajar konsep norma-norma kehidupan pelajaran pendidikan kewarganegaraan yang memeperoleh skor ratarata ketuntasan sebesar 8,93\% atau setara dengan dengan kategori sangat baik.

Selanjutnya ada pula penelitian yang dikembangkan oleh (Nanang Soffiyullah, 2015) yang berjudul pengembangan video pembelajaran berbasis materi dan soal sebagai suplemen untuk meningkatkan penguasaan konsep mata pelajaran IPA yang memperoleh respon dari siswa sebesar $90 \%$ dengan kategori baik 


\section{Pengembangan Media Pembelajaran Berbasis Video Naratif Dengan Metakognitif Pada Materi Ketenagakerjaan - Fitria Cholifatul Muthoharih \\ DOI : https://doi.org/10.31004/edukatif.v3i5.713}

dan penelitian yang dilakukan oleh (Aang Kurnia) dengan judul pengaruh penggunaan media pembelajaran visual terhadap hasil belajar ekonomi siswa kelas X semester genap SMA Negeri 1 Pekalongan yang memperoleh skor rata-rata respon positif dari siswa sebesar 86,96\% dengan kategori baik.

Kepraktisan penggunaan video naratif dengan pendekatan metakognitif pada amteri ketenagakerjaan kelas XI SMA Negeri 1 Soko dilihat dari hasil respon guru dan peserta didik yang mendapat rata-rata presentase $89,18 \%$ dengan kategori sangat layak. Respon positif siswa menunjukkan bahwa pembelajaran dengan menggunakan media pembelajaran berbasis video naratif dengan pendekatan metakognitif pada mata pelajaaran ekonomi mudah dipahami oleh siswa.

Hal ini sejalan dengan penelitian yang dilakukan oleh (Pratiwi, 2020) dengan judul pengembangan media pembelajaran audio visual dalam bentuk CD interaktif untuk meningkatkan kemampuan menulis narasi bahasa indonesia pada tema 4 berbagai pekerjaan siswa kelas IV SD/MI yang memeperoleh skor rata-rata respon positif dari siswa sebesar 7,04 dengan keterangan sangat baik.

Selanjutnya penelitian yang dilakukan oleh (Nanang Soffiyullah) yang berjudul pengembangan video pembelajaran berbasis materi dan soal sebagai suplemen untuk meningkatkan penguasaan konsep mata pelajaran IPA yang memperoleh skor rata-rata sebesar 2,38 dengan kategori baik. dalam penelitian ini ditemukan beberpa temuan yang yang selanjutnya menjadi acuan dalam proses penelitian, yang pertama, bahan pembelajaran siswa terbatas pada buku LKS saja dan cenderung memberikan efek jenuh terutama dalam kondisi pembelajaran secara virtual seperti saat ini, yang kedua dari hasil wawancara oleh guru maupun siswa, siswa seringkali tertinggal dalam hal pemahaman materi dan mengharuskan guru untuk mengulang lagi materi yang disampaikan hal ini berdampak pada efisiensi waktu. Dan yang ketiga dari kedua temuan yang telah dipaparkan sebelumnya dapat ditarik kesimpulan bahwa siswa membutuhkan media yang praktis bisa diakses dimana saja dan kapan saja, selain kemudahan tersebut sebuah media pembelajaran dapat dikatakan memenuhi syarat kepraktisan apabila (1) praktisi menyatakan bahwa media pembelajaran dapatditerapkan dilapangan dan (2) tingkat keterlaksanaan media pembelajaran masuk dalam kategori baik (Hafiz, 2013).

Penerapan mediapembelajaran video naratif dengan pendekatan metakognitif materi ketenagakerjaan kelas XI SMA Negeri 1 Soko menimbulkan dampak yang sangat positif sertaterdapat perbedaan atau peningkatan yang dilihat dari masalah dan kebutuhan yang melatarbelakangi penerapanya dalam proses pembelajaran. Peningkatan dapat dilihat dari proses pembelajran yang berlangsung dimana sebelumnya sissswa cenderung merasa jenuh dengan media yang terbatas sedangkan waktu yang tersedia saagat terbatas sehingga mengharuskan peserta didik belajar secara mandiri diluar pembelajarn bersama guru. Juga kemudahan dalam mengakses bahan materi yang diberikan guru dimana saja dan kapan saja, sebagaimana dengan penegasan dari penelitian sebelumnya meskipun dengan materi dan subjek penelitian berbeda dari (Husamah, H., \& Rahardjanto, 2018). Selain itu peserta didik menjadi lebih bersemangat untuk belajar ekonomi khususnya pada materi ketenagakerjaan karena adanya minat belajar yang didorong oleh penggunaan media belajar yang menarik yakni media pembelajaran video naratif . karena dapat diakses di rumah secara mandiri jika membutuhkan pengulangan materi yang kurang jelas karena sudah di lengkapi dengan materi dan audio yang jelas. Serta penerapan media pembelajaran video naratif memenuhikebutuhan implementasi pembelajaran daring dimasa pandemi seperti yang disampaikan oleh (Syarifudin, 2020)

Hal ini juga dibuktikan dengan keberhasilan indikator hasil belajar siswa yang meningkat yang dapat dilihat dari hasil peningkatan ketercapaian ketuntasan dari pretest-posttest dan angket respon guru serta siswa yang masing-masing mendapat skor presentase sebesar $85 \%$ dan $89,18 \%$. Oleh karena itu dapat ditarik kesimpulan bahwa video naratif yang di jadikan media pembelajaran dalam pembelajaran daring dapat digunakan sebagai alternatif media pembelajaran di masa pandemi yang menharuskan siswa melakukan pembelajaran secara mandiri dirumah yang dalam kondisi tersebut peserta didik membutuhkan media yang praktis dengan kemudahan dalam mengaksesnya dengan tampilan yang menarik. Yang selanjutnya merujuk pada penelitian dari (Yuliandari \& Wahjudi, 2016) bahwa media pembelajaran yang berbasis video dapat 
2038 Pengembangan Media Pembelajaran Berbasis Video Naratif Dengan Metakognitif Pada Materi

Ketenagakerjaan - Fitria Cholifatul Muthoharih

DOI : https://doi.org/10.31004/edukatif.v3i5.713

meningkatkan hasil belajar siswa juga penelitian dari (Rebowo, 2014) serta (Reza Rizki Ali Akbar, 2018) yang memiliki kesepakatan yang sama bahwa penerapan pengembangan video dalam proses pembelajaran memiliki tampilan yang menarik minat siswa untuk menggunakanya dan selanjutnya berdampak pada peningkatan hasil belajar.

Sehingga penelitian pengembangan ini di aplikasikan secara berbeda dengan penelitian sebelumnya diantaranya pemilihan jenis video yang berbeda yaitu video naratif dan materi yang dituju yaitu materi ketenagakerjaan pada mata pelajaran ekonomi serta penerapanya dalam pembelajaran daring. Oleh karena itu perlunya pengaplikasian media pembelajaran video naratif pada materi lain selain ketenagakerjaan serta dapat digunakan selain dalam pembelajaran daring serta dikembangkan dengan model dan metode lain sesuai kebutuhan pembelajaran.

\section{KESIMPULAN}

Berdasarkan hasil dari penelitian yang telah dilalukan, ada beberpa kesimpulan yang dapat ditarik diantaranya: 1) pengembangan media pembelajaran berbasis video naratif dengan pendekatan metakognitif pada materi ketenagakerjaan mata pelajaran ekonomi dinyatakan layak berdasarkan lembar validasi materi yang memperoleh skor rata-rata sebesar $80 \%$ yang dikategorikan "valid". Selanjutnya validasi oleh ahli $\mathrm{m}$ edia dengan memperoleh skor rata-rata $80 \%$ yang dikategorikan "valid. Serta validasi evaluasi yang memperoleh nilai rata-rata sebesar $80 \%$. Adapun secara keseluruhan rata-rata skor validasi media pembelajaranberbasis video naratif dengan pendekatan metakognitif diperoleh presentase sebesar $80 \%$ dengan kategori valid dan layak digunkan dalam proses pembelajaran. 2) Keefektifan media pembelajaranberbasis video naratif dengan pendekatan metakognitif diperoleh dari pengujian melalui lembar pretest-postest dengan nilai rata-rata sebesar $85 \%$. 3) Kepraktisan media pembelajaran berbasis video naratif dengan pendekatan metakognitif diperoleh dari lembar angket guru dan siswa dengan nilai rata-rata sebesar $89,18 \%$.

\section{DAFTAR PUSTAKA}

Anjar Purba Asmara. (2015). Pengembangan Media Pembelajaran Berbasis Audio Visual Tentang Pembuatan Koloid. Anjar Purba Asmara, 15.

Astra, I Made, A. R. S., \& Wahidah. (2017). Peningkatan Keterampilan Proses Sains Peserta Didik Melalui Model Guided Discovery Learning Kelas Xi Mipa Pada Materi Suhu Dan Kalor. Jurnal Penelitian \& Pengembangan Pendidikan Fisika.

Hafiz, M. (2013). Research And Development; Penelitian Di Bidang Kependidikan Yang Inovatif, Produktif Dan Bermakna. Jurnal Ta'adib 16, 1, 28-43.

Husamah, H., \& Rahardjanto, A. (2018). Oidde-Pjbl Learning Model: Problemsolving Skillsand Product Creativity For Study Of Biology Prospective Teachers.

L, C. (2016). Using Addie Models Of Instructional Design To Teach Chest Radiograph Interpretation.

M. Bahri Arifin, Y. A. W. (2020). Peengembangan Media Audio Visual Menggunakan Contextual Teaching And Learning (Ctl) Dalam Pembelajaran Menulis Paragraf Narasi Pada Siswa Kelas Vii Smp. Jurnal Kajian Bahasa, Sastra Dan Pengajaranya, 3.

Mansyur, A. R. (2020). Dampak Covid-19 Terhadap Dinamika Pembelajaran Di Indonesia. 1(2), 113-123.

Marhani, Aunurrahman, S. U. (2012). Pengembangan Media Video Untuk Perolehan Belajar Konsep NormaNorma Kehidupan Pelajaran Pendidikan Kewarganegaraan.

Martinis Yamin. (2012). Desaian Pembelajaran Berbasis Tingkat Satuan Pendidikan.

Muhammad Iqbal, Sri Latifah, Irwandani. (N.D.). Channel Youtube Video Blog (Vlog) Development With 
2039 Pengembangan Media Pembelajaran Berbasis Video Naratif Dengan Metakognitif Pada Materi Ketenagakerjaan - Fitria Cholifatul Muthoharih

DOI : https://doi.org/10.31004/edukatif.v3i5.713

Stem Approach As An Alternative Media. 2019.

Nanang Soffiyullah. (2015). Pengembangan Video Pembelajaran Berbasis Materi Dan Soal Sebagai Suplemen Untuk Meningkatkan Penguasaan Konsep Mata Pelajaran Ipa.

Pratiwi, I. (2020). Pengembangan Media Pembelajaran Audio Visual Dalam Bentuk Cd Interaktif Untuk Meningkatkan Kemampuan Menulis Narasi Bahasa Indonesia Pada Tema 4 Berbagai Pekerjaan Siswa Kelas Iv Sd/Mi.

Rebowo, W. A. (2014). Pengembangan Video Pembelajaran Berbasis Masalah Pada Materi Pecahan Kelas Iv Sekolah Dasar. Jurnal Guru Sdn 101872 Tumpatan Nibung.

Reza Rizki Ali Akbar, K. (2018). Pengembangan Video Pembelajaran Matematika Berbantuan Media Sosial Instagram Sebagai Alternatif Pembelajaran.

Rony Yudhi Septa Priana. (2017). Pemanfaatan Vlog Sebagai Media Pembelajaran Terintegrasi Teknologi Informasi.

Sukamadinata, \& Nana, S. (2009). Metode Penelitian Pendidikan. Sukamadinata, \& Nana, S.

Syarifudin, A. S. (2020). Implementasi Pembelajaran Daring Untuk Meningkatkan Mutu Pendidikan Sebagai Dampak Diterapkannya Social Distancing. Universitas Trunojoyo Madura.

Yuliandari, S., \& Wahjudi, E. (2016). Pengembangan Media Pembelajaran Berbasis Multimedia Interaktif Pada Mata Pelajaran Ekonomi Materi Jurnal Penyesuaian Perusahaan Jasa. Jurnal Penyesuaian Perusahaan Jasa, 1(1), 1-9. 